\title{
Examination of Historical Advancement of Corporate Governance in India- Contemporary Issues and Way Forward
}

\author{
Deepika Kulhari \\ Department of Law, \\ University of Rajasthan. \\ India \\ kulharideepika9@gmail.com \\ https://doi.org/10.48161/qaj.v1n3a73
}

\begin{abstract}
In the Era of Globalized world, the importance of Fair Corporate Governance policies has been recognized by different countries. From collapse of Wallpaper Group Coloroll in UK, Enron Scandal in US and Satyam Scam in India, all of these countries have witnessed some of the largest Corporate Scams. With the help of good Corporate Governance Policies, a country can protect its economy and investment made therein. It encourages shareholders to invest in capital market and ensure safety of their investment. In India, the corporate governance and its basic pillars on which governance stands i.e. Transparency, Accountability and Fairness, were introduced through Clause 49. This was done only after it was recommended by the Kumar Mangalam Committee. Yet, subsequently the shocking event of Satyam Scam \& other Corporate Governance failure continues to hit Indian economic on various occasions.
\end{abstract}

This paper will analyse the past experience of some of the famous scams happened in India specifically in past one decade and the lessons learnt thereby. The paper furthermore discusses the current legal issue and the challenges faced by Corporate Governance practices in India

Keywords-Corporate Governance, Scams, SEBI.

\section{INTRODUCTION}

"The moral of the twisted story is twofold - Financial crisis will always be with us and there is no magic bullet to stop them" [1]

With rapid growth in globalization, all the companies all over the world have realised importance of adopting standardised corporate governance policies to run their company. The improvised Corporate Governance can reduce the chances of financial crises and can boost economy at large. It helps the company to set their objective and monitor their performance on the basis of those objectives. [2]

Corporate governance refers to a system of principles, ethics, values, morality, rules, laws, and processes, among other things. Corporate governance is a structure in which directors are entrusted with obligations and obligations in regard to the company's operations. [3]

During 1990's London Stock Exchange, the corporate market was facing challenges, as the market structure could not regulate the lack of accountability of the listed company and misrepresentation done by its director. In 1992, Cadbury Committee was formed to address these issues and to protect the interest of the shareholders as against those of the Director. The Committee on Financial Aspects of Corporate Governance gave the 'Code of Best Practice' wherein the listed companies were required to comply with the provisions mentioned under the code.[4]

The Main components of the code given by Cadbury Committee included-

- The element of Independent Director.

- The BOD to be comprised of directors outside the Company (Having no relation whether pecuniary or otherwise with the company)

- Remuneration of BOD to be made by NonExecutive Director

- Audit Committee to include at least 3 Non Executive Directors.

These elements later become the core of Corporate Governance in UK and later were also adopted by India as well. A variety of debates and events have prompted the evolution of corporate governance in recognition of the necessity to manage corporations more effectively and professionally in order to make them internationally competitive.

The notion of corporate governance arose in India after the second half of 1996 as a result of economic liberalization and deregulation of industry and business. With the passage of time, there was also a need for firms to be more accountable to their shareholders and consumers. The Chamber of Indian Industries (CII) created the core 
rule for corporate governance in 1998. Corporate governance, according to the CII, is the management of laws, techniques, practices, and well-understood principles that determine an organization's ability to make administrative decisions - specifically, its investors, banks, clients, the State, and representatives.[5] The fundamental goal of India's corporate governance reforms was to make Audit Committees and Boards more independent, focused, and strong supervisors of management, as well as to assist shareholders, notably institutional and international shareholders/investors, in overseeing management. These reform initiatives were carried out in a variety of ways, with the Ministry of Corporate Affairs (MCA) and the Securities and Exchange Board of India (SEBI) both playing key roles. But various Scam play a significant role in changing the picture of modern Corporate Governance policies. These financial scams made the authorities look deeper into the loopholes and rethink about the policies on Corporate Governance. Further many committees were set up from time to time to examine the impact of those Scams and coming forth with better corporate governance reforms.

\section{CORPORATE SCAMS IN INDIA}

\section{A. HARSHAD MEHTA SCAM}

In 1984, Harshad Mehta became the member of Bombay stock Exchange as broker. He then incorporated his own firm under the name 'Grow More Research and Asset Management'. [6] By the end of 1990, he received huge investments made in the favour of his firm. During that time, the banking institutions were not permitted to make investments in the equity market unless they are backed with government issued securities. Also, banks were supposed to preserve ration out of their assets as Government fixed interest Bonds. Harshad Mehta convinced two banks (Bank of Karad (BOK) and the Metropolitan Co-operative Bank (MCB)) to issue him fake receipts so as to use them while dealing with securities. He then used those fake receipts to get real receipts from different banks. Other than the BOK \& MCB, the banks gave him money believing that those fake receipts used are backed by government issued securities. [7]

He was using his status to manipulate the Stock Market, as he would increase price of any particular share for his personal gain. [8] At this time, SEBI did not have authority over the transactions which took place between the stock brokers and the investors. [9] This scam lead to the breakdown of commercial banking system and affected RBI as well. The functions of stock market were severely affected by it. After the scam was discovered, there was a huge drop down in SENSEX, it then created panic among investors, lowering down the share's prices further more.

All the agencies, such as the Reserve Bank of India (RBI), the Central Bureau of Investigation (CBI), the Income Tax Department, the Directorate of Enforcement and the Joint Parliamentary Committee, were involved in the investigation of the Harshad Mehta scam. Loss of Rs. 100,000 crores were recorded in the capital market. As result of the scam, Harshad Mehta was arrested by CBI for misappropriating approximately 2.8 million shares. [10]
After the scam, some of the serious concern were raised in regard to accountability and transparency existing in securities market during 1992. The SEBI act of 1992 was amended by government of India in 1995. [11] In addition to this, SEBI was given power to issue order against company to make mandatory disclosure before issuance of securities. Harshad Mehta scam became an eye-opening event for Indian financial sector and the beginning for better Corporate Governance policies in India. Later, after the break out of another economic scam done by mastermind Ketan Parekh, the stock market was once again hit very hard. In order to improvise Corporate Governance more and make the wrong doer liable, the Amendment act of 2002 was introduced. The amendment act gave SEBI the authority to access the records of any bank and it also empowered SEBI to regulate those records. The Amendment act also empowered SEBI with the power of inspecting books maintained by the Public Listed Company. [12]

\section{B. KETAN PAREKH SCAM}

After Harshad Mehta the Ketan, Parekh scam become second most popular scam who took the Bombay stock exchange by surprise and caused the loss of about Rs. 2000 crores to the investors. Ketan Parekh would look for stocks which had low liquidity and low market capitalization. [13] And then invested in such shares immensely, therefore fictitiously increasing the trading of such shares among his own connection network. These stocks were later called as K-10 stocks, after his name. In March 2001, Sensex crashed and it was shocking for all the investors who were associated with Ketan Parekh and his stocks. After investigations, SEBI came to know that when K- 10 stock began to tumble, Ketan could not bear the loss and was out of cash soon.

It was later found that he never had enough money to buy large stocks. Therefore, he used to buy stocks which were cheap and after manipulating price of these stocks, he would pledge them with banks when those stocks were trading at higher rate. Also, he was using other brokers to trade on his behalf and he would pay them the commission or any losses they accrued while carrying out the transaction on his behalf. [14] This system was known as "badla system" (carry forward system) and Ketan Parekh was the master of this system.

On the one hand, after Sensex crashed the SEBI was looking at the volatility of the stock market, whereas RBI was looking at the data of private banks and their capital exposure. It was later found that those private banks were exceeding their limit of capital exposure, therefore making market more volatile and prone to crash. To control the collateral damage, SEBI introduced new restriction over trade. An additional $10 \%$ deposit margin was imposed on outstanding net sales in the stock markets. The Badla system was banned forever in the country. The volatility margin was reduced to $60 \%$ from $80 \%$. [15] Restrictions were imposed on short term sale such as Foreign Institutional Investors. All the members of stock exchange acting as President, Vice President or any other office bearer post at BSE were banned from trading in stock exchange. [16] 


\section{SATYAM SCAM}

The famous scam happened as its founder B. Ramalinga Raju, who was the founder of the Satyam ltd. embezzled the balance sheet his company. [17] He was inflating every financial aspect of the company i.e. profit, revenue, as well as salary accounts of the employees. The internal auditing team was found creating thousands of fake invoice generated through fake customer IDs. [18] Just before the revelation of scam Raju, the board member of the company decided to sell share of the company. Tech Mahindra ended up winning the bid, and bought shares of Satyam enterprise at a price which was three times less than the stock market price before the outbreak of the scam.

As a result, SEBI and Tech Mahindra both became fully aware about the scam and the fraud which was being carried out by Raju.[19] In the end, Raju's admission toward the fraud of approx. \$276 million came out which shook Indian stock market and the economy to its core. Satyam Scam became the face of poor Corporate Governance policies practiced in India. The irony was such that Satyam Enterprises was the one to win the "Golden Peacock Global Award" for their extra ordinary performance in Corporate Governance. [20] Beside the misrepresentation, there were other points which prove that Satyam enterprises failed to comply with Corporate Governance policies.

- There was no independent director in the BOD of Satyam Computers Ltd.

- $\quad$ The work done by Auditing Committee lacked transparency. There was an active participation of Auditing Committee in curbing the financial falsification done by the company.

- The Annual financial report of company was based on manipulated facts which were not real.

- There was lack of Due Diligence by Auditors of the company as well as by the CEO/CFO of the company.

Due to all of these reasons, the Satyam Scam become the massive example of the Corporate Governance Failure. Also, it became the turning point for major changes in corporate governance policies, which were later introduced in Companies act, 2013.

After the break out of scandal, National Association of Software and Services Companies established a Corporate Governance and Ethics Committee which was chaired by Narayana Murthy. [21] SEBI formed the committee on Disclosure and Accounting Standards. The committee issued some guidelines for the company to follow so as to improve their accounting standards, for example Auditor shall retire in rotation or CFO shall have basic qualification and experience before appointment. [22] The Ministry of Corporate Affairs also issued guidelines for the Corporate Governance. These included the concept of independent director, independent role of CEO and terms for appointment of other member of BOD.

At that time, SEBI used to regulate companies which were Publicly Listed Company through Clause 49 of the listing agreement. Clause 49 was introduced by SEBI on recommendation made by Kumar Mangalam Birla Committee. After close study of the Economic catastrophes such as Enron and WorldCom, the Narayana Murthy committee (second committee on corporate governance) further recommended few amendments to the provisions of Clause 49, such as financial disclosures, the member of auditing committee should have background of financial proficiency. [23] Furthermore, all of these recommendations were incorporated in Companies act of 2013. The role of independent director, evaluation of performance of BOD, Class action Suits, terms and conditions such as regarding appointment and remuneration of Director, all of the above provisions have be made mandatory after implementation of the Company Act 2013 .

\section{SAHARA SCAM}

Sahara Scam was discovered by SEBI because of their vigilance and their quick action, which was not the case in past. Sahara India through its two company "Sahara India Real Estate Corporation Limited" (SIRECL) and "Sahara Housing Investment Corporation" (SHIC) passed a resolution to raise funds. In order to raise fund Optionally Fully Convertible Debentures were issued to close associates of the company and their friends and family (Approx Rs.24,029 crore were raised through this fund). Later when Prospectus for Sahara Prime City was produced before SEBI for its approval, SEBI set its eyes on the fund raising event by SIRECL and SHICL.

After further investigation SEBI realised that Sahara Company is not financially viable for raising such huge amount of funds. Beside this the accurate disclosure about the company was not prescribed to the investors. Moreover the details about those who have invested were missing as well. [24] The debentures issue did not have any opening date or closing date. Both the parties were engaged in aggressive legal battle over the debentures which were alleged to be issued illegally. [25] The matter reached Securities Appellate Tribunal (SAT), they upheld the order of SEBI which was to return the money to the investor. The matter was then decided by Supreme Court. Much of the fund raised were repaid back to the investors but when Sahara failed to provide details of investor to whom refund was not provided and they also could not deposit the remaining amount with SEBI, then SC issue arrest warrant against Subrata Roy (CEO of Sahara Group). [26]

The incident was consider victory for SEBI as the scam was discover because of due diligence followed by SEBI. [27] As the security regulator the role of SEBI in protecting interest of investor and safeguarding Corporate Governance was worth praise.

\section{E. SARADHA SCAM (PONZI SCHEME)}

Ponzi scheme have been quite popular in India. It is often used by the investor of low income group who are looking for alternative option to get loan. According to Section 2(b) of the Chit Fund Act, 1982: " Chit means a transaction whether called chit, chit fund, chitty, kuree or by any other name by or under which a person enters into an agreement with a specified number of persons that every one of them shall subscribe a certain sum of money (or a certain quantity of grain instead) by way of periodical instalments over a definite period and that each such subscriber shall, in his turn, as determined by lot or by auction or by tender or in such other manner as may be 
specified in the chit agreement, be entitled to the prize amount ". Saradha group used to collect money from its investors through redeemable bonds and in return they were promised that they would receive high profits out of their investment. [28] The company hired many agents throughout West Bengal and huge deposits were received by the company. In due course Saradha group conglomerated more than 200 companies and funds of approx. $5 \$$ billion was collected from depositors. [29]

In this case as well SEBI was vigilant before scam broke out. In 2009 SEBI challenged Saradha Group, stating that they were violating Companies Act, 1956 as the act require any company which is has investors more than 50 in number, then that company needs prior permission from SEBI. [30] While expanding the market and interconnecting number of companies the Saradha Group they bought upon themselves investigation of SEBI. Later in the year 2012 the group decided to resolve this issue by converting their fund raising into Collective Investment Scheme, which seemed like chit fund which were disguised of real estate projects, such as Tourism Packages etc. [31] By that time SEBI did had power to regulate Chit Funds, yet soon SEBI realised that in fact the fund raising was not done by Chit Funds, a notice was issued to Saradha group to stop their activities immediately. The group managed to ignore SEBI's notification until the day Scandal broke out in public, creating panic among all the investors. In order to protect low income investors relief fund of US \$ 90 million was established. [32] Later, all the investigation on Saradha Group were transferred to $\mathrm{CBI}$ as it was alleged that there was political interference in the illegal activity carried by the group. [33]

\section{RECENT DEVELOPMENT AND CURRENT REGULATING MECHANISM OF CORPORATE GOVERNANCE}

\section{A. THE COMPANIES ACT OF 2013}

The Companies Act of 2013 clearly suggests that authorities are focusing on increasing board duty and accountability. The Act specifies specific governance, disclosure, and improved duties, obligations, and liabilities for the board, its committees, and independent directors.

All of the provisions of the new Company Law are helpful in establishing a sound Corporate Governance framework. Furthermore, the Companies (Amendment) Act of 2017 and the Companies (Amendment) Act of 2019 made many changes to the Companies Act of 2013, realigning sections to improve corporate governance and convenience of doing business in India while continuing to strengthen compliance and investor protection. [34]

\section{B. SEBI (LISTING OBLIGATIONS AND DISCLOSURE REQUIREMENTS) REGULATIONS, 2015.}

The Securities and Exchange Board of India regulates all listed firms. SEBI is a regulatory body that was founded on April 12, 1992. SEBI was founded with the primary goal of preventing fraud and defending the interests of its investors. Its primary goal is to control the activities of the Stock Exchange while also maintaining the healthy growth of the financial market. SEBI published specific Corporate Governance Norms in the form of Clause 49 of the Listing
Agreement to guarantee excellent corporate governance, which has now been updated and published as the "SEBI (Listing Obligations and Disclosure Requirements) Regulations, 2015". [35]

Regulation 4 of the SEBI (LODR) Regulations, 2015 establishes general standards for listed businesses' periodic disclosures and corporate governance. The principles for periodic disclosures are based on the International Organization of Securities Commissions' guidelines (IOSCO). They have also included corporate governance concepts (in line with OECD principles)

\section{RESERVE BANK OF INDIA(RBI)}

Banking and financial organizations operate differently from other corporate organizations in many respects, making excellent corporate governance of banks necessary and crucial. The RBI had made many steps to improve corporate governance in the Indian banking sector. [36]

\section{Insurance Regulatory and Development Authority of India (IRDAI)}

In a circular dated August 5, 2009, the Insurance Regulatory and Development Authority of India (IRDAI) established Guidelines on Corporate Governance for insurance businesses. Through several circulars, the Authority has also established distinct rules for the appointment/ reappointment and payment of MD/CEO as well as other Key Management Persons (KMPs), as well as the appointment of statutory auditors of insurers. In view of the changes introduced by the Act on Corporations, 2013 Video circulation Dated 18 May 2016, IRDAI revised its current guidelines to ensure that the structure, responsibilities and functions of the Executive Board and the company management reflect the expectations of all stakeholders and of the regulator. [37]

\section{E. SERIOUS FRAUD INVESTIGATION OFFICE (SFIO)}

The Serious Fraud Investigation Office (SFIO) is an organization established under the Ministry of Corporate Affairs (MCA) to investigate and prosecute white-collar crimes. For the first time, the SFIO was granted statutory force by the Company law of 2013. The 2013 Act introduces Section 447, which first defines fraud as well as penalty for such an offense to address the increasing number of corporate fraud cases in India. The main reason for include the very broad definition of fraud, an amalgam of multiple parts of the Indian Penal Code, is apparently Satyam and a couple of other company scandals which occurred during the period before the 2013 Act was considered by Parliament. [38]

\section{CONCLUSION}

A committee on Corporate Governance has been formed by SEBI in June, 2017. The committee was chaired by Uday Kotak who was Executive Chairman of Kotak Mahindra Bank. [39] In order to improve the standard of Corporate Governance in India they have provided few recommendations such as: 
- Composition of BOD: The committee was of view that there should be minimum of 6 directors on the Board of a Public Limited company instead of only 3 as per the Companies Act, 2013.

- Gender Diversity: The Kotak committee has recommended that there should be one independent woman director in BOD of every listed company.

- Quorum of the board: Committee suggested that the quorum of listed company should be higher than the requirement provided under the Companies Act.

- Key Managerial Position: The committee was of the view that listed company with shareholding of more than $40 \%$ shall have separate chair for MD and CEO.

- Committee Meeting: The committee recommended that Audit Committee of Listed company should meet atleast five times in one year and other Committees should mandatorily meet at least one time in a year.

- Related Party Transaction: With the aim of strengthening the transparency in related party transaction, the committee was of view that there should be half yearly disclosure of the transactions on the website of the listed companies within. [40]

All of these recommendations have been accepted by SEBI, LODR (Listing Obligation and Disclosure Requirements) Regulations, provide with effect from April 1, 2020. The recommendations were made in contrast to global practices of corporate governance and with keeping in mind the recent incidence of economic crimes and short coming thereon. [41]

There are number of regulatory authorities governing Corporate Governance presently such as- SEBI, RBI, SFIO, and IRDAI. Yet there has not been given enough coverage to unlisted corporation and their corporate management. The over lapping of multiple authorities brings vagueness rather than solution to major issues. The above discussion clearly show that the economic crimes have heavily impacted the regulatory framework of the Corporate Governance in India. Following the discovery of each Corporate Scam, quick action was taken against the fraudulent party, and regulatory flaws were exposed. As a result, it may be said that one of the reasons why the incident occurred was due to regulatory shortcomings. The Kotak Mahindra Committee was also created in light of the increasing prevalence of Scams (Nirav Modi, Vijay Mallya Scam). Individuals looted in the past because they were aware of a gap in the corporate governance regulatory structure. Aside from regulatory shortcomings, one of the key reasons for the occurrence of corporate scams is corporate behavior that intends to take unfair advantage of legal gaps. Corporates governance should not be the end goal for any Corporations, rather it should be the core of every organization at the very beginning. This attitude adjustment will not only uplift and improve corporations from within, but they will also end up providing quality of service to the rest of the world.
[1] Rodrik, Dani. "Who Needs Capital Account Convertibility?", Essays in International Finance 207, Princeton, New Jersey: Princeton University, 1998, PP. 1-90, Available At https://ies.princeton.edu/pdf/E207.pdf

[2] CSV Murthy, -'Entrepreneurship and Good Governance" ,1st edition, Himalaya publication, with ISBN No. 9789350244678, pp. No. 161-226,2010, Available at - http://iosrjournals.org/iosr$\mathrm{jbm} /$ papers/Vol16-issue3/Version-3/A16330107.pdf, Accessed on 31 May 2021

[3] OECD Principles of Corporate Governance (1999). Avaiable at https://www.oecd.org/officialdocuments/publicdisplaydocumentp $\mathrm{df} /$ ? cote $=\mathrm{C} / \mathrm{MIN}(99) 6 \&$ docLanguage $=\mathrm{En}$, Accessed on 30 May, 2021.

[4] Cadbury, Sir Adrian, "The Code of Best Practice", Report of the Committee on the Financial Aspects of Corporate Governance, Gee and Co Ltd, 1992.

[5] Bhumesh Verma, \& Himani Singh, Evolution of Corporate Governance in India, SCC Online Blog, PL (CL) November 69,2019, Available at https://www.scconline.com/blog/post/2019/11/13/evolution-ofcorporate-governance-in-india/, Accessed on 30 May 2021

[6] Parikh, Daksesh, Katiyar, "Spreading Shockwaves", India Today (8 January 2013), Retrieved 30 May 2021

[7] Sucheta Dalal, Debashis Basu, "The Scam: from Harshad Mehta to Ketan Parekh, also includes JPC FIASCO and Global Trust Bank Scam" (8th ed.). Mumbai: Kensource Publications (2014), Retrieved 25, May 2021.

[8] Goel, U., Kumar, S., Singh, K., \& Manrai, R.. "Corporate Governance: Indian Perspective With Relation To Sarbanes Oxley Act." Proceedings of The International Conference on Economics and Development, 1(1), (2017), 60-72., Available athttps://doi.org/10.17501/iced.2017.1106, Accessed on 1 June , 2021

[9] Nagarajan, G And Khaja Sheriff. J. "White Collar Crimes in India," International Journal of Social Science and Inter disciplinary Research, Vol.1 Issue 9, September 2012 p. 114-124. Available

http://indianresearchjournals.com/pdf/IJSSIR/2012/September/16. pdf, Accessed on 29 May 2021

[10] SEBI Press Release, "Action against Harshad Mehta, Videocon, BPL and Sterlite," 2001, Available at https://www.sebi.gov.in/media/press-releases/apr-2001/actionagainst-harshad-mehta-videocon-bpl-and-sterlite_17608.html, Accessed on 1 June, 2021.

[11] The Securities Laws (Amendments) Act 1995, Available At https://www.sebi.gov.in/acts/act15.pdf, Accessed on 1 June, 2021

[12] Inserted by The Securities Laws (Amendments) Act of 2002

[13] Malini Bhupta, "2001-Ketan Parekh scam: Stock and bull story", India Today, December 18, 2009, available at http://indiatoday.intoday.in/story/2001-

Ketan+Parekh+scam:+Stock+and+bull+story+/1/75489.html (Accessed on 30 May 2021).

[14] Vivek Law, "What went wrong with India's first regulator, SEBI?", India Today Magazine, November 12, 2001, Last UPDATED: September 28, 2012, Available at https://www.indiatoday.in/magazine/economy/story/20011112what-went-wrong-with-indias-first-regulator-sebi-774613-200111-12, Accessed on 25 May 2021

[15] "The Ketan Parekh Scam", IBS Center for Management Research (ICMR), 2002, Available https://www.icmrindia.org/free\%20resources/casestudies/ketanparekh-scam-5.htm, Accessed on 30 May,2021.

[16] Pooja Sharma, "Impact of Securities and Financial Scams on Regulatory Framework", Science Arena Publications International journal of Business Management, Vol, 1 (1): 7791,2016., Available athttps://sciarena.com/storage/models/article/jOZJ5mmRakZ2Kt3O YoBC3iWhW4CZu2tCYUoAa6LoHR7wYMtciCt31yuPXvee/im pact-of-securities-and-financial-scams-on-regulatoryframework.pdf, Accessed on 27 May, 2021.

[17] Bobins Abraham, "5 Of The Biggest Corporate Scammers In India", India Times News, Updated on May 04, 2017 Available at https://www.indiatimes.com/news/india/6-of-the-biggestcorporate-scammers-inindia-251861.html, Accessed at 27 May 2021 
[18] S. Ramachadran, "Raju Brings Down Satyam, Shakes India," Asia Times Online Ltd., 2009. Available at www.a.times.com (Accessed 1 June, 2021)

[19] S. S. Dagar, "How Satyam Was Sold the Untold Story: How the IT Services Major Was Rescued against all Odds", Business Today Reconstructs the Events of the 14 Crucial Weeks that Led up to the Sale," Business Today, 2009, pg. 25-42.

[20] The award was revoked after the scam was publicly discovered.

[21] "Nasscom announces formation of Corporate Governance and Ethics Committee," Business Standard, Last Updated at January 25, 2013. Available at -,https://www.businessstandard.com/article/press-releases/nasscom-announcesformation-of-corporate-governance-and-ethics-committee109021100123_1.html, Accessed on 29 May,2021.

[22] SEBI Committee on Disclosures and Accounting Standards (SCODA) is the standing Committee of SEBI that advises on matters relating to disclosures and accounting standards, 2009, Available https://www.sebi.gov.in/sebi_data/attachdocs/1289624747835.pdf Accessed on 30 May,2021.

[23] N. R Narayana Murthy, "Report of the SEBI Committee on Corporate Governance", SEBI, 2003, Available at https://www.nfcg.in/UserFiles/narayanamurthy2003.pdf, Accessed on 1 June, 2021

[24] Sahara India Real Estate Corporation Limited \& Ors. versus Securities and Exchange Board of India \& Anr., order dated August 31, 2012 in Civil Appeal No. 9813 and 9833 of 2011

[25] "Apex court directs Sahara Group firm to provide details on OFCD scheme," Business Lines, The Hindu, Updated on March $\begin{array}{lccc}\text { 12, } & 2018 . & \text { Available at } \\ \text { https://www.thehindubusinessline.com/companies/apex-court- }\end{array}$ directs-sahara-group-firm-to-provide-details-on-ofcdscheme/article20240980.ece1?ref=relatedNews, Accessed on 27 May, 2021.

[26] "Subrata Roy Sahara surrenders before Police in Lucknow", IANS(Indo-Asian News Service ), February 28, 2014, Available at https://news.biharprabha.com/2014/02/subrata-roy-saharasurrenders-before-police-in-lucknow/, Accessed on 30 May 2021.

[27] "Sahara and the Super Cops",The Indian Express, March 6, 2014 Available https://indianexpress.com/article/opinion/columns/sahara-and-thesuper-cops/, Accessed on 29 May 2021.

[28] Subhanil Chowdhury, "The Political Economy of Shadow Finance in West Bengal", Economic and Political Weekly, 2013, Available At- https://www.epw.in/journal/2013/18/webexclusives/political-economy-shadow-finance-west-bengal.html

[29] Soudhriti Bhaban "Anger mounts over Saradha fund crisis as thousands of depositors face ruin", Daily Mail, 2013, Available at https://www.dailymail.co.uk/indiahome/indianews/article2313658/Anger-mounts-Saradha-fund-crisis-thousandsdepositors-face-ruin.html?ito=feeds-newsxml, Accessed on 1 June, 2021

[30] Namrata Acharya , "In Bengal's grey 'money market', Saradha is just one", Business Standard, Last Updated at April 26, 2013, Available at -https://www.businessstandard.com/article/companies/in-bengal-s-grey-money-marketsaradha-is-just-one-113042600611_1.html, Accessed on 1 June, 2021.
[31] "Before The Securities And Exchange Board Of India Coram: Rajeev Kumar Agarwal, Whole Time Member", SEBI Order WTM/RKA/ERO-CIS/19/2013, Available at -Available at https://www.sebi.gov.in/sebi_data/attachdocs/1366731012533.pdf , Accessed on 30 May, 2021.

[32] BS Reporter "Mamata sets up fund for duped Saradha investors", Business Standard, Last Updated at April 24, 2013, Available at https://www.business-standard.com/article/currentaffairs/mamata-sets-up-fund-for-duped-saradha-investors113042400602 1.html, Acessed on 1 June 2021.

[33] BS Reporter, "SC jolt for Mamata: CBI to probe Saradha scam", Business Standard, Last Updated at May 10, 2014, Available at https://www.business-standard.com/article/current-affairs/sc-joltfor-mamata-cbi-to-probe-saradha-scam-114050900345_1.html, Accessed on 1 June 2021.

[34] Trilegal "India: Companies (Amendment) Act 2017 - Key Changes", Mondaq, 02 February 2018, Available athttps://www.mondaq.com/india/corporate-and-companylaw/670216/companies-amendment-act-2017--key-changes, Accessed on - 1 June, 2021.

[35] "SEBI (Listing Obligations and Disclosure Requirements) Regulations, 2015 (Listing Regulations)", 03, Sept, 2015, Available at - https://www.sebi.gov.in/media/press-releases/sep2015/sebi-listing-obligations-and-disclosure-requirementsregulations-2015-listing-regulations-_30603.html, Accessed on 1 June 2021.

[36] Shyamala Gopinath, "Corporate Governance: Towards Best Practices", Reserve Bank of India Bulletin, 2004, Available athttps://rbidocs.rbi.org.in/rdocs/speeches/pdfs/61586.pdf, Accessed on 30 May,2021.

[37] Guidelines by IRDAI"Corporate Governance Guidelines for Insurers in India", IRDA/F\&A/GDL/CG/100/05/2016, Available at-

https://www.irdai.gov.in/ADMINCMS/cms/LayoutPages_Print.as px?page=PageNo2852, Accessed on - 29 May, 2021.

[38] Bharat Vasani and Esha Himadri, "Serious Fraud Investigation Office - Keeping a close watch on frauds in India Inc", Lexology, $\begin{array}{llll}\text { February } & 24 & 2021, \quad \text { Available at }\end{array}$ https://www.lexology.com/library/detail.aspx?g=c3aa335f-c19e4ec3-9f20-78ed7370bd93, Accessed on 1 June, 2021.

[39] Medha Srivastava and Adamya Vikran, "India: Analysis Of Kotak Committee Recommendations On Corporate Governance", Mondaq Online, 03 January 2020, Available at https://www.mondaq.com/india/corporategovernance/875864/analysis-of-kotak-committeerecommendations-on-corporate-governance, Accessed on - 1 June, 2021.

[40] Uday Kotak, "Report submitted by the Committee on Corporate Governance", Securities and Exchange Board of India, October 5, 2017 pp. 25-26, Available at https://www.nfcg.in/KOTAKCOMMITTEREPORT.pdf, Accessed on - 1 June,2021.

[41] Cyril Shroff \& Amita Katragadda, "India : Corporate Governance Law and Regulations 2020", The International Comparative Legal Guides and the International Business Reports are published by: Global Legal Group, Available At - https://iclg.com/practiceareas/corporate-governance-laws-and-regulations/india, Accessed on - 1 June, 2020. 